\title{
Merske značilnosti slovenskega prevoda Lestvic za ocenjevanje nadarjenosti GRS-S
}

\author{
Žan Lep* in Valentin Bucik \\ Oddelek za psihologijo, Filozofska fakulteta, Univerza v Ljubljani
}

\begin{abstract}
Povzetek: Postopek prepoznavanja nadarjenih je strokovno zahtevno opravilo, delo z nadarjenimi učenci pa $\mathrm{v}$ domačem in mednarodnem okolju prepoznano kot izjemno pomembno. Slovenski Koncept odkrivanja in dela $\mathrm{z}$ nadarjenimi je tudi $\mathrm{v}$ tujini prepoznan kot primer dobre prakse, trenutno pa poteka njegova prenova. Vzporedno s pripravo prenovljenega Koncepta odkrivanja in dela z nadarjenimi bi morali psihologi zagotoviti tudi metodološko ustrezne pripomočke za učiteljevo oceno nadarjenosti učencev. Ker so v šolskem okolju prav učitelji ključni pri identifikaciji nadarjenih učencev, v članku opisujeva postopek prevoda in priredbe Lestvic za ocenjevanje nadarjenosti GRS-S (Pfeiffer in Jarosewich, 2003), ki jih za ocenjevanje na področjih intelektualnih sposobnosti, učne učinkovitosti, ustvarjalnosti, umetniških talentov, vodstvenih sposobnosti in motivacije lahko uporabljajo učitelji ali drugi mentorji. Poleg preverjanja merskih značilnosti sva zbrala še mnenja ocenjevalcev in izvedla konvergentno preverjanje veljavnosti z obstoječimi Ocenjevalnimi lestvicami za oceno nadarjenosti učenca (OLNAD07). V študiji je sodelovalo 36 učiteljev razrednega pouka iz vse Slovenije, ki so skupaj ocenili 175 učencev četrtega razreda osnovne šole. Rezultati kažejo na ustrezne psihometrične značilnosti prevedenih lestvic (visoka notranja skladnost, kriterijska veljavnost, ustrezna faktorska struktura) in ustrezno konvergentno veljavnost pri primerjavi z OLNAD07. Do slednjih so učitelji precej kritični, predlagane lestvice GRS-S pa ocenjujejo kot primernejši pripomoček za ocenjevanje nadarjenosti. $V$ zaključku predlagava izvedbo standardizacijske študije pri večjem vzorcu in morebitno vpeljavo lestvic v postopek identifikacije nadarjenih.
\end{abstract}

Ključne besede: Lestvice za ocenjevanje nadarjenosti - GRS, nadarjeni, osnovnošolci, merske značilnosti, veljavnost

\section{Psychometric characteristics of the Slovene translation of the Gifted Rating Scales (GRS-S)}

\author{
Žan Lep* and Valentin Bucik \\ Department of Psychology, Faculty of Arts, University of Ljubljana, Slovenia
}

\begin{abstract}
The importance of individualized work with gifted students has been acknowledged in both domestic and international environments, and the process of gifted student identification is a professionally demanding one. The Slovene Concept of Identifying and Working with Gifted Students, which has been internationally cited as an example of good practice, is currently being renewed. Psychologists should simultaneously secure methodologically sound instruments for the teachers to assess giftedness in students, as they are indispensable in identifying the gifted in educational settings. In the present article, we describe the process of translation and adaptation of the Gifted Rating Scales GRS-S (Pfeiffer \& Jarosewich, 2003) into Slovene. The scales could be used by teachers and other mentors to assess their students' potentials and abilities in areas of intellectual and academic ability, creativity, artistic talent, leadership, and motivation. We looked into the psychometric characteristics of the scales, gathered the raters' comments about them, and conducted a convergent validity analysis with the currently used Scales for the Teacher's Assessment of Giftedness (OLNAD07). Thirty-six teachers from around Slovenia participated in the study and rated the giftedness of 1754 th grade students. The translated scales exhibit good psychometric characteristics (high internal consistency, criterion validity, factorial structure) and satisfactory convergent validity with OLNAD07. While the participating teachers are in general wary of the present instrument, they feel the proposed GRS-S scales are more suitable for use in the identification process. We thus propose a standardization study to be conducted with a larger sample and we propose the possibility of implementing the scales into the process of working with the gifted in Slovenia.
\end{abstract}

Keywords: Gifted rating scales - GRS, gifted, elementary school students, metric characteristics, test validity

\footnotetext{
${ }^{*}$ Naslov/Address: asist. Žan Lep, Oddelek za psihologijo, Filozofska fakulteta, Univerza v Ljubljani, Aškerčeva 2, 1000 Ljubljana, e-mail: zan.lep@ff.uni-lj.si
}

Članek je licenciran pod pogoji Creative Commons Attribution 4.0 International licence. (CC-BY licenca).

The article is licensed under a Creative Commons Attribution 4.0 International License (CC-BY license). 


\section{Opredelitev nadarjenosti in odkrivanje nadarjenih}

Nadarjenost V strokovni literaturi ni enoznačno opredeljena; pri posameznikih se kaže v različnih oblikah in obsegih, jasno dojemanje koncepta in razvoja nadarjenosti ter uporaba zanesljivih in veljavnih načinov prepoznavanja pa sta ključna, saj postopek prepoznavanja nadarjenih učencev ${ }^{1}$ ne služi zgolj odkrivanju nadarjenih, temveč je namenjen predvsem spodbujanju njihovih potencialov skozi vzgojnoizobraževalno delo (Davidson, 2009; Juriševič, 2011).

Danes so v stroki najbolj uveljavljeni večdimenzionalni modeli izrednih sposobnosti na različnih področjih, ki poleg inteligentnosti vključujejo tudi sposobnosti na specifičnih področjih in psihološke značilnosti ter osebnostne značilnosti (pregled v Heller idr., 2000; Sternberg in Davidson, 2005; Stoeger, 2009; Subotnik, Olszewski-Kubilius in Worrell, 2011). Tudi Lestvice za ocenjevanje nadarjenosti, s katerimi se bova ukvarjala $\mathrm{v}$ nadaljevanju, temeljijo na enem takih modelov, Münchenskem modelu nadarjenosti (Heller, 2004), ki ločuje med napovedniki in kriteriji nadarjenosti. Med napovednike v modelu sodijo različne sposobnosti in veščine (npr. ustvarjalnost, intelekt, socialne veščine), kriteriji pa predstavljajo realizirano nadarjenost in zajemajo različna področja delovanja, na katerih posameznik dosega visoke rezultate (npr. matematika, umetniška področja, šport, socialni odnosi). Končno pa na odnos med omenjenima konstruktoma vplivajo osebnostni (storilnostna naravnanost, motivacija, nadzor, učne strategije) in okoljski moderatorji (družinsko okolje, razredna klima, pričakovanja učiteljev).

Različne mednarodne prakse in raziskave (npr. Juriševič, 2011; Kaufman in Sternberg, 2019; McClain in Pfeiffer, 2012; pregled v Freeman, Raffan in Warwick, 2010) poročajo o širokem naboru metod za prepoznavanje nadarjenih, med katerimi so najpogostejše učiteljeve ocene in nominacije, skupinski testi dosežkov in inteligentnosti, testi ustvarjalnosti, podatki, pridobljeni od staršev in drugih, ocena šolskega psihologa ter dosežki in uspehi učenca. Pestrost metod ne preseneča, saj je $\mathrm{v}$ procesu identifikacije za celosten pregled pomembno pridobiti kar največ različnih podatkov in upoštevati različne kriterije, kot to izhaja iz sodobnih opredelitev nadarjenosti (Brown idr., 2005; Shore idr., 1991).

V Sloveniji je trenutno uveljavljen tristopenjski model prepoznavanja nadarjenih, ki obsega evidentiranje, identificiranje ter seznanitev staršev s pridobivanjem njihovega mnenja (Žagar idr., 1999). V procesu evidentiranja strokovni delavci predlagajo širši nabor učencev, ki bi lahko bili nadarjeni, nato pa $\mathrm{v}$ procesu identifikacije učence ocenijo $\mathrm{s}$ psihometričnimi metodami. Pri tem naj bi skrbeli za pripravo, izbor in uporabo metodološko neoporečnih pripomočkov, da zagotovijo merjenje želenih lastnosti, zanesljivost in nepristranskost (Boben, 2006).

Za učiteljevo oceno različnih področij nadarjenosti učenca $v$ procesu identifikacije $v$ Sloveniji je Ekspertna skupina za delo $\mathrm{z}$ nadarjenimi $\mathrm{v}$ osnovni in srednji šoli pri

\footnotetext{
${ }^{1} \mathrm{~V}$ besedilu uporabljene moške slovnične oblike veljajo generično za vse spole (npr. učenec/učenka, učitelj/učiteljica, svetovalni delavec/svetovalna delavka).
}

Zavodu Republike Slovenije za šolstvo (ZRSŠ; v nadaljevanju Ekspertna skupina) razvila Ocenjevalne lestvice nadarjenosti učenca (OLNAD07; Ekspertna skupina za delo z nadarjenimi $\mathrm{v}$ osnovni in srednji šoli, 2008). OLNAD07 sestavlja 10 lestvic za oceno področij nadarjenosti, ki izhajajo iz Koncepta: splošno intelektualno, učno, ustvarjalno, voditeljsko, telesnogibalno, tehnično ter umetniško (to se deli na glasbeno, likovno, literarno in dramsko). Vsako od lestvic sestavlja osem trditev, ki jih eden ali več ocenjevalcev ocenjuje na 7-stopenjski lestvici ( 1 - sploh ne velja, 7 - popolnoma velja). Kriterij za identifikacijo učenca kot nadarjenega je doseganje rezultata, ki je enak ali višji od 90. percentila glede na norme, ki temeljijo na standardizacijskem slovenskem vzorcu (Ekspertna skupina za delo $\mathrm{z}$ nadarjenimi $\mathrm{v}$ osnovni in srednji šoli, 2008). Lestvice so visoko zanesljive (koeficienti notranje skladnosti so v validacijski raziskavi znašali med $0,92$ in 0,98$)$, s faktorsko analizo pa so avtorji izločili sedem faktorjev, ki so skupaj pojasnili $80 \%$ variance postavk.

Kljub psihometrični ustreznosti lestvic OLNAD07 (ustrezna je predvsem zanesljivost, manj pa veljavnost) je njihova uporabnost $\mathrm{v}$ praksi vprašljiva. $\mathrm{V}$ strokovni javnosti se pojavljajo številni pozivi k posodobitvi instrumentarija, premisleku o opredeljenih področjih ter celo k upoštevanju mnenja staršev v procesu identifikacije (pregled v Juriševič, 2012; Žagar, 2012). M. Juriševič, B. Stritih, N. Fabjančič in P. Gradišek (2012) so pri sicer manjšem vzorcu psihologov ugotovile, da skoraj dve tretjini svetovalnih delavcev psihologov OLNAD07 ocenjuje kot manj primeren za uporabo v identifikaciji (bil naj bi neselektiven, učiteljem nerazumljiv, njegova uporaba težavna, kakovost odgovorov pa zato vprašljiva). Večina udeležencev v omenjeni raziskavi se tudi ne strinja s primernostjo uravnoteženosti različnih pripomočkov (Ravenove progresivne matrike, Torranceovi testi ustvarjalnosti, OLNAD07), saj menijo, da bi morale imeti lestvice OLNAD07 zaradi subjektivnosti v postopku identifikacije manjšo težo ali pa bi morale biti ustrezno uravnotežnene oziroma potrjene $\mathrm{z}$ drugimi tovrstnimi merami. Podobno menijo tudi sodelujoči V Analizi uresničevanja Koncepta (Bezić in Deutsch, 2011).

Zaradi ozke opredelitve področij OLNAD07 (predmetni) učitelj z njimi pri učencu težko ocenjuje nekatera področja, saj ga $v$ takšnem okolju ne pozna (npr. razredni učitelj pri ocenjevanju literarnega ali glasbenega področja). Lestvice so hkrati agregirane (združevanje učnih in ustvarjalnih sposobnosti $\mathrm{v}$ eno lestvico) in razdrobljene; umetniška področja so ločena na posamezne lestvice, kar naj bi olajšalo ocenjevanje, a hkrati podaljšuje pripomoček, vprašanja pa so podrobna, kar lahko vodi $\mathrm{v}$ težave $\mathrm{z}$ razumljivostjo in zmožnostjo učitelja, da učenca ustrezno oceni na posameznem področju nadarjenosti. Lestvice so na spletu prosto dostopne, način ocenjevanja (opredeljevanje, ali lastnost za učenca velja) pa lahko vodi v slabše ločevanje med učenci z različnimi sposobnostmi. Ker učencev pri uporabi OLNAD07 ne primerjamo med sabo (kot je to potrebno pri lestvicah GRS-S), lahko učitelji pri ocenjevanju izraženosti neke lastnosti številnim učencem pripišejo visoke ocene, čeprav ta pri vseh od njih ni izražena nadpovprečno.

T. Jarosewich, Pfeiffer in Morris (2002) so v svojem pregledu pripomočkov za učiteljevo oceno nadarjenosti učenca v ZDA identificirali le tri uporabne pripomočke, pri 
vseh pa izpostavili vprašljivo tehnično primernost, veljavnost, ustreznost standardizacijskih postopkov ter nezadovoljive napovedne veljavnosti. To je bil glavni povod za oblikovanje novega pripomočka, ki smo ga prevedli in preverili $\mathrm{v}$ slovenskem jezikovnem in kulturnem okolju.

\section{Lestvice za ocenjevanje nadarjenosti (GRS)}

Lestvice za ocenjevanje nadarjenosti (Gifted Rating Scales; GRS; Pfeiffer in Jarosewich, 2003) so namenjene ocenjevanju otrok, starih od 4 do 14 let in obsegajo dve obliki: predšolsko (4-7 let) ter šolsko (do vstopa $v$ srednjo šolo). Sestavljene so iz petih (predšolska) oziroma šestih lestvic (šolska oblika): intelektualne sposobnosti, učna učinkovitost, ustvarjalnost, umetniški talent, vodstvene sposobnosti (le šolska oblika) in motivacija. Šolska oblika v interpretacijo ponudi pet skupnih rezultatov, ki kažejo na možno nadarjenost otroka na katerem od področij, motivacija pa ni opredeljena kot svoje področje nadarjenosti, ampak predstavlja splošnejšo mero učenčeve zavzetosti in želje po uspehu in velja za pomembno determinanto nadarjenosti.

Avtorja sta pri zasnovi težila $\mathrm{k}$ načelom preprostosti uporabe, metodološke ustreznosti, preproste interpretacije, fleksibilnosti in povezanosti s pripomočki za ocenjevanje inteligentnosti, kot so Wechslerjeve lestvice inteligentnosti. Utemeljene so na širokem teoretičnem ozadju, ki upošteva značilnosti normativnih predpisov $\mathrm{v}$ ZDA in najnovejša spoznanja na področju nadarjenosti (pregled $v$ Pfeiffer in Jarosewich, 2003). Razvite so bile v sodelovanju z učitelji in za uporabo zahtevajo minimalno uvajanje. Uporabljena konceptualizacija nudi okvir, ki olajšuje identifikacijo, učitelje pa spodbuja k objektivnejšemu ocenjevanju. Tega lahko zaradi zadovoljive konvergentne veljavnosti potrdimo tudi z rezultati učenca na (objektivnejših) testih dosežkov in drugih oblikah ocenjevanja nadarjenosti (preizkusi ustvarjalnosti, inteligentnosti, listovnik, intervju, dosežki), kar v praksi omogoča učinkovito in izčrpno ocenjevanje nadarjenosti posameznika. Poleg tega lestvice temeljijo na sodobnih spoznanjih o nadarjenosti, omogočajo sodelovanje med različnimi pedagoškimi delavci, ki podajo celostno oceno, in omogočajo zgodnje prepoznavanje nadarjenosti (že v predšolskem obdobju), kar so hkrati tudi ključni poudarki izhodišč, predstavljenih v Konceptu. Ker izhajajo iz podobne opredelitve nadarjenosti kot slovenski Koncept (Marlandov in Münchenski model; glej McClain in Pfeiffer, 2012; Heller, 2004), se zdita smiselna njihov prevod $\mathrm{v}$ slovenščino in prirejanje za rabo v Sloveniji.

Lestvice so zanesljive in veljavne, kar potrjujejo različne študije (npr. Li idr., 2008b; Pfeiffer in Jarosewich, 2007; Rosado, Pfeiffer in Petscher, 2008). Avtorja izvirnih lestvic poročata o zadovoljivi sočasni veljavnosti na podlagi primerjave ocen z že obstoječimi pripomočki za ocenjevanje sposobnosti in nadarjenosti (Pfeiffer in Jarosewich, 2003), kriterijsko veljavnost lestvic pa so npr. raziskovalci pri kitajskem vzorcu preverjali preko poveznosti z doseženimi točkami na zaključnih preizkusih (Li idr. 2008b), pri južnokorejskem pa z lokalnim preizkusom za učiteljevo oceno šolske uspešnosti (Lee in Pfeiffer, 2006). Obe študiji podpirata kriterijsko veljavnost lestvic GRS.
Pri včasih sicer relativno majhnih vzorcih so se izkazale kot diagnostično učinkovit pripomoček, ki dobro ločuje med različnimi skupinami učencev. Lestvice so uporabne tudi pri identifikaciji nadarjenih iz depriviligiranih skupin in manjšin (Li idr., 2009; Pfeiffer in Jarosewich, 2007; Pfeiffer in Petscher, 2008; Pfeiffer, Petscher in Jarosewich, 2007; Pfeiffer, Petscher in Kumtepe, 2008); Erwin in Worrell (2012) sta ugotovila, da so omenjene lestvice trenutno edini takšen pripomoček.

Poleg ameriškega izvirnika sta obe obliki lestvic prevedeni in prirejeni za rabo v različnih kulturnih okoljih, npr. kitajskem (Li idr. 2008b; Petscher in Li, 2008; Siu, 2010), južnokorejskem (Lee in Pfeiffer, 2006), turškem (Karadağ, Karabey in Pfeiffer, 2016), portoriškem (Rosado idr., 2008; 2015), omanskem (Hassan Hemdan Mohamed idr., 2017), brazilskem (de Cássia Nakano in Siqueira, 2012) in italijanskem (Beretta, Pfeiffer in Zanetti, 2014) ter ustrezne za spletno administracijo (Yarnell in Pfeiffer, 2015). Povsod so se izkazale kot uporaben pripomoček, merske značilnosti pa sovpadajo z značilnostmi izvirnika. Lestvice so preko različnih kulturnih okolij konfiguralno in metrično invariantne (predlagana faktorska rešitev je ustrezna $\mathrm{v}$ vsakem od njih), med kulturami pa tudi ne prihaja do pomembnih odstopanj $\mathrm{v}$ testnih rezultatih (Li idr., 2009). Poleg ocen učiteljev so raziskovalci pri kitajskem vzorcu potrdili tudi uporabnost lestvic za pridobivanje ocen staršev (Li idr., 2008a; Petscher in Li, 2008).

\section{Cilji raziskave}

Strokovni delavci v Sloveniji so kritični do načinov identifikacije, ki vodijo do precenjevanja nadarjenosti učencev in visokega števila učencev, ki so prepoznani kot nadarjeni - Slovenija s 25-30 \% identificiranih učencev odstopa od mednarodnega povprečja (glej Juriševič, 2011). Slednje negativno vpliva tudi na zaznano kakovost dela Ekspertne skupine in Koncepta kot celote, ki pa je v mednarodnem prostoru prepoznan kot kakovosten (Cseh, 2011; Győri, 2013). Pomanjkljivosti obstoječih pripomočkov za prepoznavanje nadarjenosti (tj. OLNAD07) bi tako lahko presegli z uporabo pripomočka GRS-S, ki se je v tujini izkazal kot najbolj zanesljiv in veljaven pripomoček za merjenje in prepoznavanje nadarjenosti ter je skladen s pri nas uporabljenim konceptom nadarjenosti.

V okviru študije sva tako prevedla lestvice GRS-S, ustrezno priredila posamezne postavke ter pri vzorcu slovenskih osnovnošolskih učiteljev preverila njegove merske značilnosti (notranjo strukturo, zanesljivost, kriterijsko in konvergentno veljavnost ter razlike v dosežkih med spoloma). V pilotni študiji sva preverila ustreznost postavk in načina vzorčenja, $v$ glavni pa sva poleg merskih značilnosti lestvic GRS dosežke učencev primerjala tudi z rezultati na lestvicah OLNAD07 ter tako ugotavljala konvergentno veljavnost predlaganega pripomočka.

Glede na izsledke M. Juriševič in sodelavk (Juriševič idr., 2012), ki ugotavljajo kritičnost šolskih psihologov do OLNAD07, so naju zanimala tudi mnenja učiteljev. Ker naj bi lestvice v postopku identifikacije služile predvsem njim, sva preverjala njihova stališča do obeh pripomočkov. Pričakovala 
sva, da se bo kritični odnos šolskih svetovalnih delavcev pokazal tudi med učitelji, zanimalo pa naju je, kako bodo zaznavali ustreznost prevedenih lestvic GRS-S.

$\mathrm{Z}$ izvedbo raziskave sva želela začeti postopek razvoja pripomočka, ki ga lahko ponudimo učiteljem in svetovalnim delavcem, da bodo učinkoviteje, lažje in bolj objektivno, predvsem pa bolj stabilno (zanesljivo) in veljavno ocenjevali učence, ter tako kot nadarjene prepoznali tiste učence, ki izkazujejo visok potencial na katerem od opredeljenih področij nadarjenosti.

\section{Metoda}

\section{Udeleženci}

V obeh študijah sva $\mathrm{k}$ sodelovanju povabila svetovalne delavce iz osnovnih šol. Ti so na šolah vodili postopek ocenjevanja in $\mathrm{k}$ sodelovanju povabili učitelje razrednega pouka, ki so iz svojega razreda vzorčili učence; vsak učitelj je ocenil od tri do pet učencev, izbranih glede na kriterije, opredeljene v navodilih (glej poglavje Postopek). Na tak način nisva imela stika $\mathrm{z}$ učitelji, izpolnjenih odgovornih listov pa ne moreva povezati $\mathrm{z}$ ocenjenim učencem, kar vsem (posrednim) udeležencem raziskave nudi popolno anonimnost.

$\mathrm{V}$ pilotni študiji so sodelovali svetovalni delavci, ki se intenzivneje ukvarjajo s področjem nadarjenosti, npr. udeležba na izobraževanjih, strokovno delo. Na povabilo se jih je odzvalo 15 (vabljenih 18), dva pa zaradi odsotnosti učitelja oz. nepripravljenosti na sodelovanje izpolnjenih ocenjevalnih pol nista vrnila. Skupaj so učitelji v pilotni študiji ocenili 75 učencev (37 deklet in 38 dečkov) četrtega razreda, starih od 9 do 11 let.

V glavni študiji sva $\mathrm{k}$ sodelovanju povabila svetovalne delavce 189 osnovnih šol iz celotne Slovenije (naključno sva vzorčila po razvidu osnovnih šol Ministrstva za izobraževanje, znanost in šport). Ocenjevalne pole je skupaj izpolnilo 36 učiteljev razrednega pouka iz 20 osnovnih šol, ki trenutno poučujejo v četrtem razredu in imajo med 3 in 39 let delovnih izkušenj $(M=20,14 ; S D=9,93)$. Vsi učitelji poučujejo učence že vsaj od štiri do šest mesecev in ocenjujejo, da svoje ocenjene učence poznajo precej ali zelo dobro. Skupaj so ocenili 175 učencev četrtega razreda ( 86 deklet in 89 dečkov). Med ocenjenimi je bilo 50 učencev $(28,6 \%, 27$ deklet in 23 dečkov), ki so bili z uporabo lestvic OLNAD07 predhodno že identificirani kot nadarjeni. $\mathrm{O}$ učiteljih nisva pridobivala dodatnih informacij, o učencih pa poleg ocen iz obeh pripomočkov le podatek o starosti in spolu.

Vzorec predstavlja slab odstotek vseh učencev četrtega razreda rednega programa osnovne šole, kar je primerljivo z vzorci, uporabljenimi v sorodnih študijah (npr. Li idr., 2009). Vzorec je bil ustrezno uravnotežen glede zastopanosti mestnih in podeželskih okolij: ocenjenih je bilo 105 učencev šol iz mestnih naselij ali naselij mestnih občin (60\%) ter 70 učencev podeželskih šol (40 \%), kar ustreza prebivalstveni strukturi Republike Slovenije (Razpotnik, 2018).

Manjkajoče vrednosti so bile obravnavane v skladu $\mathrm{Z}$ navodili $\mathrm{v}$ priročniku izvirnih lestvic (nadomeščanje $\mathrm{s}$ povprečjem lestvice), pri ocenah, ki so jih o obeh pripomočkih podali učitelji, pa zaradi naključnih manjkajočih vrednosti navajava ločene numeruse.

\section{Pripomočki}

\section{Lestvice za ocenjevanje nadarjenosti (GRS-S)}

Lestvice za ocenjevanje nadarjenosti - šolska oblika (Gifted Rating Scales-School form; GRS-S; Pfeiffer in Jarosewich, 2003) so namenjene učiteljem, ki vedenje učenca na podlagi lastnih opažanj ocenijo na šestih področjih: intelektualne sposobnosti (npr. Razmišlja prodorno, intuitivno razume probleme), učne (akademske) sposobnosti (npr. Razume zapleteno šolsko snov), ustvarjalnost (npr. Izkazuje bujno domišljijo, razmišlja in ravna domiselno), umetniški talent (npr. Izkazuje visoko razvito umetniško tehniko in/ ali pristop), vodstvene sposobnosti (le šolska oblika; npr. Razrešuje medvrstniška nesoglasja) in motivacija (npr. Zastavi si zahtevne cilje).

Vsaka od lestvic vsebuje 12 postavk, ki jih učitelji ocenjujejo na 9-stopenjski lestvici v dveh korakih. V prvem koraku učitelji razvrstijo vedenje učenca $\mathrm{v}$ primerjavi $\mathrm{z}$ enako starimi vrstniki v šolskem okolju v eno od treh skupin (podpovprečno, povprečno, nadpovprečno), v drugem določijo oceno znotraj skupine (nizko, povprečno, visoko). Lestvice lahko izpolnjujejo učitelji, ki učenca poznajo »precej dobro« (ga poučujejo vsakodnevno vsaj en mesec, sicer pa avtorja predlagata daljše obdobje, skladno tudi s slovensko prakso, ki predvideva ocenjevanje po vsaj treh mesecih poučevanja; glej Bezić idr., 2009). Če se učitelj pri ocenjevanju umetniških talentov ne počuti kompetentnega, lahko področje oceni predmetni učitelj ali drug mentor. Dosežek učenca pri lestvici predstavlja vsota ocen vseh postavk, pretvorjena v $T$-vrednost (po ena manjkajoča vrednost pri lestvici se lahko nadomesti s povprečjem lestvice; Pfeiffer in Jarosewich, 2003)

Izvirne lestvice (Pfeiffer in Jarosewich, 2003) so visoko notranje skladne; v skupini učencev, starih med 9 in 11 let, ki je primerljiva z zbranimi slovenskimi rezultati, so znašali koeficienti notranje skladnosti med 0,97 (vodenje) in 0,99 (intelektualne sposobnosti, talent, motivacija). Retestna zanesljivost izvirnih lestvic v obdobju sedmih dni se je izkazala kot visoka: koeficienti med 0,83 (umetniški talent) in 0,96 (motivacija), v povprečju pa okrog 0,90 . Visoki ali zelo visoki so v izvirnih lestvicah bili tudi koeficienti skladnosti med ocenjevalci za istega učenca (med 0,70 za umetniški talent in 0,84 za učne sposobnosti).

Korelacije med posameznimi lestvicami so bile visoke in teoretično upravičene; gibajo se med 0,60 (povezanost med vodenjem in motivacijo) ter 0,93 (povezanost med intelektualnimi in učnimi sposobnostmi). Avtorja opisujeta ustrezno konvergentno in diskriminativno veljavnost, ocenjeno prek povezav lestvic GRS-S z dosežki na WISC-IV, WIAT-II, vprašalniki motivacije in vodstvenih sposobnosti (Pfeiffer in Jarosewich, 2003; 2007), ter ustrezno kriterijsko veljavnost (različne skupine nadarjenih dosegajo pomembno višje rezultate na lestvicah od številčno uravnotežene kontrolne skupine tistih učencev, ki niso bili identificirani kot nadarjeni). V razvoju vprašalnika je bila predvidena 6faktorska struktura pripomočka, stabilnost strukture in druge merske lastnosti pa so bile ustrezne tudi v drugih jezikovnih različicah (npr. Li idr., 2008a; Rosado idr., 2008), čeprav avtorja opozarjata tudi na možnost združevanja faktorjev intelektualnih in učnih sposobnosti (Pfeiffer in Jarosewich, 2003). 


\section{Vprašalnik o pripomočkih za učiteljevo oceno nadarjenosti}

Vprašalnik, sestavljen za potrebe raziskave, obsega pet vprašanj, skozi katera so učitelji podali svojo oceno primernosti vsakega od obeh pripomočkov (OLNAD07 in GRS-S). $\mathrm{Na} 5$-stopenjski lestvici (1 - zelo neprimeren, 5 - zelo primeren) so ocenili posamezne vidike obeh pripomočkov (preprostost uporabe, razumljivost navodil, razumljivost ocenjevanih področij/postavk, vsebinska ustreznost merjenih področij, izčrpnost, objektivnost, razločljivost in trajanje izpolnjevanja), ocene po želji razložili in zapisali svoja dodatna opažanja ter mnenja o GRS-S (Prosimo, zapišite svoja dodatna opažanja, mnenja in pripombe o Lestvicah za ocenjevanje nadarjenosti GRS-S in posameznih postavkah). Poročali so tudi, ali bi, če bi bile te na voljo, raje kot OLNAD07 uporabili GRS-S ter svojo odločitev obrazložili (Ali bi, če bi bile na voljo, raje uporabili Lestvice za ocenjevanje nadarjenosti GRS-S kot trenutni pripomoček OLNAD07? Prosimo, da na kratko razložite, zakaj bi jih ali jih ne bi uporabili).

Pri pripravi vprašalnika in opredelitvi vidikov sva izhajala iz vprašalnika, ki so ga svetovalnim delavcem razdelile M. Juriševič in sodelavke (Juriševič idr., 2012) ter njihovih ugotovitev in kritik obstoječega instrumentarija za učiteljevo oceno nadarjenosti (Bezić in Deutsch, 2011; Juriševič, 2012). Od svetovalnih delavcev sva pridobila tudi podatke, zbrane z lestvicami OLNAD07; te so za učence, za katere so bili podatki na voljo, svetovalni delavci izpisali iz zbirnih listov (učitelji lestvic niso ponovno izpolnjevali).

\section{Postopek}

\section{Prevod Lestvic za ocenjevanje nadarjenosti}

Izvirne lestvice so bile kupljene pri ameriškem založniku Pearson, pridobljeno pa je bilo tudi soglasje za priredbo in uporabo $\mathrm{v}$ raziskovalne namene. Šolsko obliko lestvic sta $\mathrm{V}$ slovenščino prevedla dva diplomirana psihologa, ki imata izkušnje s prevajanjem psihometričnih pripomočkov iz angleškega $\mathrm{v}$ slovenski jezik. Vzvratni prevod sta neodvisno opravila magister anglistike ter univerzitetna diplomirana anglistka $\mathrm{z}$ doktoratom s področja edukacijskih ved, pri primerjavi izvirnika ter vzvratnega prevoda pa sta sodelovala še univerzitetno diplomirana anglistka in doktor psihologije. Končen nabor postavk v slovenščini je pregledala strokovnjakinja, ki se poklicno ukvarja s področjem dela $\mathrm{z}$ nadarjenimi, in zagotovila terminološko ustreznost postavk. Navodila za izpolnjevanje ocenjevalnih pol so bila prirejena slovenskemu vzgojno-izobaževalnemu sistemu, končna oblika vprašalnika pa $\mathrm{v}$ pilotni študiji poslana učiteljem, ki niso imeli pripomb o razumljivosti in primernosti postavk.

\section{Pilotna študija}

$\mathrm{K}$ sodelovanju $\mathrm{v}$ pilotni študiji sva povabila manjšo skupino svetovalnih delavcev, ki se intenzivneje ukvarjajo s področjem nadarjenosti (npr. udeležba na izobraževanjih, strokovno delo) oz. jih to področje zanima. Svetovalni delavec (oz. šola), ki se je odločil za sodelovanje, je izbral ustrezne učitelje, zatem pa sva na šolo po pošti poslala paket ocenjevalnih pol z navodili, ki jih je ta razdelil učiteljem. $\mathrm{S}$ pomočjo opisanega postopka sva učiteljem in učencem zagotovila primerno stopnjo anonimnosti.

Ker se v večini šol takrat pričnejo postopki identifikacije nadarjenih (uporaba OLNAD07), sva $\mathrm{k}$ sodelovanju povabila učitelje razrednega pouka $v$ četrtem razredu. Poleg tega so za učence četrtega razreda razvite tudi lestvice OLNAD07 (Ekspertna skupina za delo $\mathrm{z}$ nadarjenimi v osnovni in srednji šoli, 2008), na voljo pa so tudi podatki, potrebni za navzkrižno validacijo. Zaradi manjše časovne razlike med ocenjevanjema se poveča tudi možnost oz. smiselnost primerjave ocen učenca na obeh lestvicah (GRS-S in OLNAD07) in olajša primerjavo obstoječega pripomočka z novim.

Učitelji so $\mathrm{v}$ skladu $\mathrm{z}$ navodili izbrali po enega učenca, ki v razredu izkazuje zelo podpovprečne, podpovprečne, povprečne, nadpovprečne in zelo nadpovprečne sposobnosti, pri čemer so poskušali vzorec uravnotežiti po spolu, in jih ocenili z lestvicami GRS-S. Glede povprečnosti učencev učitelji niso dobili dodatnih navodil, pomembno je bilo le, da jih po svojem občutku izberejo iz celotnega spektra sposobnosti in potencialov. Način izbire udeležencev, katerega cilj je zagotavljanje heterogenega vzorca, je skladen s predhodnimi validacijskimi študijami obravnavanega pripomočka (npr. Li idr., 2008b; Pfeiffer idr., 2008) in omogoča, da z relativno majhnim številom ocenjenih učencev zajamemo širok spekter sposobnosti in potencialov.

Izpolnjene pole so učitelji predali svetovalnemu delavcu, ki je na polo prepisal povprečne skupne dosežke za vsako od področij OLDNAD07 ali označil, da učenec z OLNAD07 ni bil ocenjen oz. z njimi ni bil identificiran kot nadarjen. Omenjene podatke sva uporabila $\mathrm{v}$ postopku preverjanja konvergentne veljavnosti.

Po izpolnjevanju Lestvic za ocenjevanje nadarjenosti (GRS-S) so učitelji izpolnili vprašalnik, s katerim so ocenili prevedeni pripomoček in ga primerjali z obstoječimi lestvicami OLNAD07. Izpolnjena gradiva so svetovalni delavci zbrali in poslali avtorjema.

Tabela 1. Mere prileganja preverjenih modelov v konfirmatorni faktorski analizi

\begin{tabular}{lrrrrrrrr}
\hline Model & $\chi^{2}$ & $d f$ & $p$ & CFI & SRMR & RMSEA & $90 \%$ IZ & BIC \\
\hline $6 \mathrm{~F}$ & 5764,15 & 2469 & $<0,001$ & 0,890 & 0,035 & 0,087 & $0,084-0,090$ & 31070,14 \\
1F & 12591,74 & 2484 & $<0,001$ & 0,662 & 0,076 & 0,152 & $0,150-0,155$ & 37867,76 \\
6F z nadrednim F & 5882,90 & 2478 & $<0,001$ & 0,886 & 0,059 & 0,089 & $0,086-0,092$ & 31170,91 \\
Bifaktorski & 5404,83 & 2462 & $<0,001$ & 0,902 & 0,068 & 0,083 & $0,080-0,086$ & 31250,47 \\
\hline
\end{tabular}

Opomba: $\mathrm{F}$ - faktor, $6 \mathrm{~F}$ - šestfaktorski model, $1 \mathrm{~F}$ - enofaktorski model. Za oceno parametrov je bila uporabljena cenilka ML. Bifaktorski model ni bil identificiran, zato smo faktorske uteži na skupnem (merskem) faktorju izenačili. 


\section{Glavna študija}

$\mathrm{K}$ sodelovanju $\mathrm{v}$ glavni študiji sva povabila svetovalne delavce, jim po telefonu oz. e-pošti predstavila načrt raziskave in posredovala navodila $\mathrm{z}$ opisom poteka raziskave in njenih ciljev. Tokrat sva poslala manjše število osebnih povabil, ob tem pa iz Razvida osnovnih šol MIZŠ naključno izbrala 200 šol in poskusila stopiti v stik z njimi (na nekaterih šolah svetovalni delavci ali njihovi podatki niso bili dosegljivi, zato sva k sodelovanju skupaj povabila 189 šol).

Zaradi želje po uravnoteženosti vzorca, zbranega v pilotni študiji (veliko učencev ocenjenih $\mathrm{z}$ izrazito nizkimi ali visokimi ter malo s povprečnimi ocenami), sva učitelje tokrat prosila, da glede na izkazane sposobnosti pri delu v razredu izberejo po enega podpovprečnega in nadpovprečnega učenca ter do tri povprečne. Od tu dalje je postopek, z izjemo načina vzorčenja učencev, potekal enako kot v pilotni študiji.

\section{Rezultati z razpravo}

\section{Pilotna študija}

V pilotni študiji sva preverjala vedenje posameznih postavk ter porazdelitev dosežkov pri posameznih lestvicah GRS. Ker gre pri izvedbi pilotne študije za podporno študijo, ki naju utrjuje $\mathrm{v}$ tem, da so najnini koraki $\mathrm{v}$ nadaljevanju pravilni, na tem mestu navajava tudi rezultate analiz, ki bi lahko bili predstavljeni tudi za predstavitvijo notranje strukture, ki sva jo pregledala $\mathrm{v}$ glavni študiji.

Glede na opisne statistike $(M=4,42-6,15, S D=1,85-2,92$, $\left.A s=-0,37-0,23, S E_{\text {as }}=0,28, S p l=-1,54-(0,66), S E_{\text {spl }}=0,55\right)$ nobena od postavk ni problematična $\mathrm{v}$ smislu zbiranja preveč homogenih ocen; pri vsaki so učitelji uporabili ocene od 1 do 7. Problematična pa je bila porazdelitev sumarnih dosežkov pri posameznih lestvicah GRS (notranje strukture pripomočka $\mathrm{v}$ pilotni študiji sicer nismo preverjali, za orientacijo pa smo dosežke izračunali kot $\mathrm{v}$ izvirniku). Ti so se za razliko od izvirnika, pri katerem so bile porazdelitve normalne, porazdeljevali bimodalno (veliko podpovprečnih in nadpovprečnih ter manj povprečnih učencev). $\mathrm{V}$ glavni študiji sva tako zbirala ocene učiteljev za relativno večje število povprečnih učencev.

Kljub relativno majhnemu vzorcu v pilotni študiji, ki pa je bil primerljiv z vzorcem posamezne starostne skupine izvirnega pripomočka (Pfeiffer in Jarosewich, 2003), so rezultati nakazovali na visoko notranjo skladnost lestvičnih dosežkov (vse $\alpha=0,99$ ), korelacije med lestvicami GRS pa so bile nekoliko višje ( $r$ med 0,78 in 0,98 ), a vsebinsko primerljive s povezanostmi med lestvicami izvirnika. Na podlagi opisanih rezultatov postavk nisva spreminjala.

\section{Glavna študija}

\section{Notranja struktura GRS-S}

Veljavnost notranje strukture pripomočka GRS-S sva preverjala $\mathrm{s}$ konfirmatorno faktorsko analizo. To sva za preverjanje šestfaktorske strukture izvirnika in nekaterih prevodov (npr. Li idr., 2008b) izvedla $\mathrm{z}$ uporabo $\mathrm{R}$ paketa lavaan (Rosseel, 2012). Prileganje modela ni bilo povsem ustrezno (glej tabelo 1), povezanosti med faktorji pa so zelo visoke ( $r=0,71-0,98$; glej tabelo 4$)$, zato sva preverila še enofaktorsko, šestfaktorsko rešitev $\mathrm{z}$ enim nadrednim faktorjem in bifaktorsko rešitev, $\mathrm{s}$ katero lahko, kljub nekaterim omejitvam, preverimo pristranskost zaradi metode ocenjevanja (Podsakoff idr., 2003). Tudi ti modeli se podatkom ne prilegajo povsem zadovoljivo (glej tabelo 1); medtem ko je rešitev $\mathrm{z}$ nadrednim faktorjem primerljiva rešitvi brez njega, je prileganje enofaktorske rešitve precej slabše, pri bifaktorskem modelu pa model ni bil identificiran; poleg tega po izenačenju faktorskih uteži na skupnem (merskem) faktorju uteži nekaterih postavk pri faktorju vodenje niso statistično značilne.

$\mathrm{V}$ tabeli 2 so tako prikazane standardizirane uteži indikatorjev posameznih faktorjev in deleži pojasnjene variance postavk $\left(R^{2}\right)$ pri vsakem od faktorjev šestfaktorske rešitve $\mathrm{z}$ nadrednim faktorjem. Faktorska utež vsake od postavk je statistično značilna (vsi $Z \geq 5,48$, vsi $p<0,001$ ); gibljejo se med 0,88 in 0,98 ter nakazujejo na visoke povezanosti med postavkami in njihovimi nadrednimi faktorji.

Kljub temu, da sta prileganji obeh šestfaktorskih modelov primerljivi, je model brez nadrednega faktorja problematičen zaradi visokih korelacij med faktorji, ki ne podpirajo ločevanja nekaterih področij, kljub teoretičnim opredelitvam nadarjenosti, ki predvidevajo različna podorčja, na katera vplivajo skupni dejavniki. $Z$ vidika teoretične utemeljenosti je zato smiseln tudi model $\mathrm{z}$ nadrednim faktorjem, pri čemer pa slednjega ne gre interpretirati le kot splošno mero nadarjenosti, ampak tudi kot splošno zaznavo učitelja (oz. napako ocenjevalca, na katero opozarja tudi bifaktorska rešitev). Ta je deloma posledica tudi siceršnje neobjektivnosti pri ocenjevanju (Juriševič idr., 2012), deloma pa lahko izhaja tudi iz načina vzorčenja, ki je od učiteljev že pri izbiri ocenjenih učencev zahtevah splošne vtise.

$\mathrm{V}$ prihodnje bi bilo tako nujno opraviti dodatne študije in opisane modele preveriti pri večjem vzorcu ter poleg strukture pripomočka raziskati tudi implicitne teorije nadarjenosti, ki jih uporabljajo slovenski učitelji in bi lahko bile izvor napake pri ocenjevanju. Predhodne raziskave (Ekspertna skupina za delo $\mathrm{z}$ nadarjenimi $\mathrm{v}$ osnovni in srednji šoli, 2008) namreč opozarjajo na njihove težave pri razločevanju različnih področij nadarjenosti, kar vpliva na veljavnost podatkov zbranih s še tako prefinjenim pripomočkom.

Tabela 2. Obsegi faktorskih uteži in pojasnjenih varianc za predlagano šestfaktorsko rešitev

\begin{tabular}{lcc}
\hline & $\begin{array}{c}\text { obseg stand. } \\
\text { uteži }\end{array}$ & obseg $R^{2}$ \\
\hline Intelektualne sposobnosti & $0,94-0,98$ & $0,89-0,96$ \\
Učne sposobnosti & $0,92-0,98$ & $0,85-0,96$ \\
Ustvarjalnost & $0,90-0,98$ & $0,81-0,96$ \\
Talent & $0,93-0,97$ & $0,86-0,93$ \\
Motivacija & $0,87-0,96$ & $0,76-0,92$ \\
Vodenje & $0,88-0,97$ & $0,78-0,94$ \\
\hline
\end{tabular}


Tabela 3. Opisne statistike dosežkov na lestvicah GRS-S

\begin{tabular}{|c|c|c|c|c|c|c|c|c|c|}
\hline & $M$ & $M d n$ & $S D$ & As & $S p l$ & Min & $\operatorname{Max}$ & $P 90^{I}$ & $\overline{r^{2}}$ \\
\hline Intelektualne sposobnosti & 61,31 & 58 & 29,30 & 0,00 & $-1,23$ & 12 & 108 & 102,0 & 0,94 \\
\hline Učne sposobnosti & 63,91 & 63 & 29,30 & $-0,09$ & $-1,22$ & 12 & 108 & 103,0 & 0,91 \\
\hline Ustvarjalnost & 57,52 & 56 & 26,79 & 0,09 & $-0,95$ & 12 & 108 & 96,4 & 0,90 \\
\hline Talent & 59,60 & 60 & 24,96 & 0,05 & $-0,78$ & 12 & 108 & 94,0 & 0,91 \\
\hline Vodenje & 64,24 & 66 & 26,80 & $-0,11$ & $-1,07$ & 12 & 108 & 100,4 & 0,87 \\
\hline Motivacija & 65,90 & 66 & 26,01 & $-0,12$ & $-1,05$ & 13 & 108 & 101,4 & 0,87 \\
\hline
\end{tabular}

Opombe: $N=175, S E_{\text {as }}=0,18, S E_{\mathrm{spl}}=0,37 ;{ }^{1} 90$. percentil dosežkov pri lestvici; ${ }^{2}$ povprečna interkorelacija med postavkami znotraj lestvice.

\section{Opisne statistike za lestvice GRS-S in pretvorba dosežkov}

Povprečni skupni dosežki pri lestvicah se gibljejo med 57,52 in 65,90 točk (od 108 možnih), nekatere lestvice so asimetrične (koeficienti asimetričnosti med $-0,12$ in 0,09 ), vse pa zmerno do precej platikurtične (koeficienti sploščenosti med $-1,23$ in $-0,78$; glej tabelo 3 ). Vseeno pa porazdelitev podatkov pomembno ne odstopa od sploščenosti lestvic OLNAD07 (tudi tam so razporeditve na vseh, razen na glasbenem področju, nekoliko levo asimetrične ter sploščene), zato porazdelitve v nadaljevanju obravnavava kot normalne. Rezultati pri vseh lestvicah, razen motivacije, so $\mathrm{v}$ razponu od najnižje do najvišje mogoče vrednosti (med 12 in 108 točk; na lestvici motivacije je najnižji surovi dosežek 13 točk), povprečne interkorelacije med postavkami pa se gibljejo med 0,87 in 0,94 .

$\mathrm{V}$ tabeli 4 so prikazane povezanosti med posameznimi lestvicami, ki so skladne z rezultati iz drugih študij (npr. Li idr., 2008b). Vse so statistično značilne ter zmerno do zelo visoke; gibajo se med 0,71 (vodenje-intelektualne sposobnosti) in 0,95 (intelektualne-učne sposobnosti). Najkonsistentejše so povezave lestvice motivacije $\mathrm{z}$ ostalimi lestvicami, kar ustreza predpostavki sestavljavcev, ki motivacije ne opredeljujeta kot enega od področij, ampak kot splošno nagnjenost k razvijanju potencialov. Korelacije med lestvicami prevedenega pripomočka so $\mathrm{v}$ povprečju nekoliko višje od korelacij v izvirnem pripomočku (med 0,64 ter 0,93 ), a se odnosi med lestvicami v veliki meri ohranjajo.

$\mathrm{V}$ skladu s priročnikom izvirnega pripomočka sva rezultate normalizirala in pretvorila $\mathrm{v}$ celoštevilske $T$ vrednosti. V skladu $\mathrm{z}$ veljavnimi slovenskimi kriteriji za potrebe izvedbe nadaljnjih statističnih analiz $\mathrm{v}$ skupino nadarjenih štejeva tiste učence, ki so na kateri od lestvic
GRS-S dosegli točke $\mathrm{v}$ zgornjih desetih odstotkih standardizacijskega vzorca (nad 91. percentilom oz. T-vrednostjo 63).

Pretvorbena tabela je $\mathrm{v}$ primerjavi $\mathrm{z}$ izvirnim pripomočkom nekoliko zamaknjena navzgor; za doseganje iste $T$-vrednosti mora slovenski učenec doseči višji surov rezultat, kar je najbrž posledica manj strogega ocenjevanja sodelujočih učiteljev (učenci $\mathrm{v}$ vzorcu povprečno dosegajo višje rezultate). V nadaljevanju poročava o statističnih izračunih za standardizirane rezultate ( $T$-vrednosti), ki omogočajo neposredno primerjavo z izvirnikom.

Čeprav je vzorec za ustrezno izvedbo večnivojske analize podatkov premajhen, sva za lestvice GRS vseeno ocenila koeficiente intraklasne korelacije. $\mathrm{Z}$ njimi lahko $\mathrm{v}$ najinem primeru (vsak učitelj je ocenil več učencev) pojasnimo delež variance dosežkov, ki ga lahko pripišemo ocenjevalcem (učiteljem) ter tako pridobimo posredni vpogled $\mathrm{v}$ objktivnost preizkusa oz. $\mathrm{v}$ sistematične razlike $\mathrm{v}$ povprečjih ocen različnih učiteljev. Koeficienti se gibljejo med ICC $=0,00$ (učne sposobnosti) ter $\mathrm{ICC}=0,09$ (umetniški talent ter ustvarjalnost). Predvidevamo lahko, da je vpliv ocenjevalca razmeroma nizek, a je preizkus manj objektiven pri lestvicah, kjer je tudi merjenje dosežkov manj objektivno. Bi bilo pa to dobro preveriti $\mathrm{z}$ izvedbo večnivojskih analiz pri večjih vzorcih, vsaj pri lestvicah, kjer ICC presega vrednost 0,05 .

\section{Zanesljivost}

Posamezne lestvice GRS-S so visoko notranje skladne; koeficienti $\alpha$ znašajo vsaj 0,99 (tabela 5) in tako nekoliko presegajo koeficiente izvirnih lestvic (med 0,97 in 0,99 ). Notranje skladnosti z izločanjem postavk ne moremo zvišati; zaradi visokih zanesljivosti bi bilo morda smiselno razmisliti celo o krajšanju pripomočka. Ob tem je sicer potrebno

Tabela 4. Korelacije med faktorji v šestfaktorski rešitvi ter med standardiziranimi dosežki na lestvicah GRS-S

\begin{tabular}{lrrrrrr}
\hline & I & A & U & T & V \\
\hline (I) Intelektualne sposobnosti & - & 0,98 & 0,93 & 0,79 & 0,72 & 0,88 \\
(A) Učne sposobnosti & 0,95 & - & 0,94 & 0,82 & 0,75 & 0,91 \\
(U) Ustvarjalnost & 0,90 & 0,91 & - & 0,84 & 0,77 & 0,90 \\
(T) Talent & 0,75 & 0,77 & 0,84 & - & 0,80 & 0,84 \\
(V) Vodenje & 0,71 & 0,73 & 0,78 & 0,79 & - & 0,81 \\
(M) Motivacija & 0,83 & 0,86 & 0,87 & 0,81 & 0,80 \\
\hline
\end{tabular}

Opombe: pod diagonalo so prikazane korelacije med standardiziranimi dosežki na lestvicah GRS-S, nad diagonalo pa korelacije med faktorji $\mathrm{v}$ šestfaktorski rešitvi brez nadrednega faktorja; vse korelacije so statistično značilne pri $p<0,001$. 
Tabela 5. Zanesljivost in povprečne interkorelacije med postavkami posameznih lestvic GRS-S

\begin{tabular}{lrrrr}
\hline Lestvica & $M$ & $\alpha$ & $95 \% \mathrm{IZ}$ & $\bar{r}$ \\
\hline Intelektualne s. & 5,11 & 0,995 & $0,993-0,996$ & 0,94 \\
Učne s. & 5,33 & 0,992 & $0,990-0,994$ & 0,91 \\
Ustvarjalnost & 4,79 & 0,991 & $0,989-0,993$ & 0,90 \\
Talent & 4,97 & 0,991 & $0,989-0,993$ & 0,91 \\
Vodenje & 5,35 & 0,987 & $0,983-0,989$ & 0,87 \\
Motivacija & 5,49 & 0,987 & $0,984-0,990$ & 0,87 \\
\hline
\end{tabular}

opozoriti na to, da so bile postavke za posamezno lestvico v poli postavljene skupaj, kar bi ocenjevalce lahko napeljevalo k bolj uniformnemu odgovarjanju (npr. halo učinek), ocene zanesljivosti pa bi zato lahko bile precenjene. Je pa takšna postavitev predvidena tudi $\mathrm{v}$ izvirnih lestvic, kar vseeno omogoča primerjavo z njimi.

$\mathrm{V}$ tabeli 6 poleg koeficientov zanesljivosti navajava prav tako visoke povprečne interkorelacije med postavkami posameznih lestvic; gibajo se med 0,87 (motivacija, vodstvene sposobnosti) in 0,94 (intelektualne sposobnosti). V primerjavi z lestvicami OLNAD07 so višji koeficienti notranje skladnosti in povprečne interkorelacije med postavkami; prvi se pri OLNAD07 gibljejo med 0,92 (tehnično) in 0,98 (splošno intelektualno in učno), slednji pa med 0,63 (tehnično) in 0,87 (splošno intelektualno področje).

Zaradi časovnih in kadrovskih omejitev $\mathrm{v}$ sklopu raziskave nisva preverjala retestne zanesljivosti pripomočka in skladnosti med ocenjevalci, česar bi se morali lotiti $\mathrm{v}$ prihodnosti. Sicer rezultati raziskav z izvirnimi lestvicami kažejo na visoko retestno zanesljivost ( $r$ med 0,83 in 0,90 ) $\mathrm{v}$ obdobju enega tedna in zadovoljivo skladnost med ocenjevalci (za starostno skupino 9-11 let so koeficienti skladnosti med 0,60 in 0,77). Slednje je v slovenskem okolju še posebno pomembno, saj Koncept (Žagar idr., 1999) predvideva, da istega učenca oceni več strokovnih delavcev, kar je smiselno le ob uporabi zanesljivega pripomočka. Preverjanje retestne zanesljivosti bi bilo smiselno tudi v daljših intervalih, kar je pomembno zaradi potreb po kontinuiranemu spremljanju in ocenjevanju nadarjenih, na katerega opozarjajo v stroki (npr. Juriševič, 2011; Žagar idr., 1999) in nekateri od učiteljev, ki so sodelovali v najini študiji.

\section{Kriterijska veljavnost}

Kriterijsko veljavnost sva ugotavljala s primerjanjem dosežkov skupine učencev, ki so bili na podlagi rezultatov OLNAD07 identificirani kot nadarjeni, s številčno enako veliko in naključno izbrano skupino ostalih učencev (tistih, ki niso bili ocenjeni ali niso dosegli dovolj visokega rezultata). Predhodno identificirani učenci dosegajo pomembno višje rezultate na vseh lestvicah GRS-S z visokimi velikostmi učinka (Cohenov $d$ med 1,12 in 1,40; glej tabelo 6).

Podobni vzorci razlik so opazni tudi pri podrobnejši analizi posameznih področij: učno nadarjeni (ustrezno visok rezultat na lestvici učnega področja OLNAD07) dosegajo na GRS-S višje rezultate na povezanih lestvicah intelektualnih, učnih sposobnosti in ustvarjalnosti, pa tudi na področju motivacije; razlike so statistično značilne $\mathrm{z}$ visokimi velikostmi učinka ( $p<0,001, d$ med 1,03 in 1,29$)$. Razlike med skupinama so sicer nekoliko manjše kot v izvirniku, a je potrebno poudariti, da so avtorji izvirnih lestvic $v$ skupino intelektualno nadarjenih vključili učence $\mathrm{z}$ izjemnimi rezultati na preizkusih inteligentnosti (dosežek nad 120 točk na WISC-IV ali sorodnem pripomočku).

$\mathrm{V}$ skupino umetniško nadarjenih sva uvrstila učence, ki so bili identificirani na podlagi vsaj ene od umetniških lestvic OLNAD07 ter njihove rezultate primerjala z rezultati ostalih učencev. Umetniško nadarjeni poleg višjih rezultatov $(t[60,66]=6,36, p<0,001, d=1,38)$ na lestvici umetniškega talenta GRS-S dosegajo višje rezultate $\mathrm{z}$ visokimi učinki tudi na drugih lestvicah GRS-S. Višje rezultate na lestvici umetniškega talenta dosegajo tudi nadarjeni na posameznih področjih: glasbenem $(t[30,42]=3,93, p<0,001, d=1,16)$, literarnem $(t[41,81]=6,04, p<0,001, \mathrm{~d}=1,71)$, likovnem $(t[25,30]=3,36, p=0,001, d=1,15)$ in dramskem področju $(t[36,54]=2,92, p=0,003, d=0,92)$, kjer so razlike med lestvicami najmanjše.

\section{Razlike med spoloma}

V povprečju dekleta na vseh lestvicah dosegajo višje rezultate kot dečki; do razlik prihaja na lestvicah umetniškega talenta, vodstvenih sposobnosti in motivacije, na katerih dekleta dosegajo višje rezultate: v povprečju za 17,5 točk

Tabela 6. Primerjava dosežkov nadarjenih učencev z dosežki kontrolne skupine

\begin{tabular}{|c|c|c|c|c|c|c|c|c|c|c|}
\hline & \multicolumn{3}{|c|}{ Nadarjeni } & \multicolumn{2}{|c|}{ Ostali } & \multirow[b]{2}{*}{$\Delta M$} & \multirow[b]{2}{*}{$t$} & \multirow[b]{2}{*}{$d f$} & \multirow[b]{2}{*}{$p$} & \multirow[b]{2}{*}{$d$} \\
\hline & $n$ & $M$ & $S D$ & $M$ & $S D$ & & & & & \\
\hline Intelektualne sposobnosti & 50 & 58,64 & 6,67 & 47,30 & 9,28 & 11,34 & 7,02 & 88,94 & $<0,001$ & 1,40 \\
\hline Učne sposobnosti & 50 & 58,58 & 6,80 & 48,04 & 8,87 & 10,54 & 6,67 & 91,82 & $<0,001$ & 1,33 \\
\hline Ustvarjalnost & 50 & 57,80 & 6,07 & 46,76 & 9,55 & 11,04 & 6,90 & 82,99 & $<0,001$ & 1,38 \\
\hline Talent & 50 & 56,30 & 7,73 & 45,98 & 9,18 & 10,32 & 6,08 & 95,23 & $<0,001$ & 1,22 \\
\hline Vodenje & 50 & 56,50 & 8,01 & 46,30 & 10,06 & 10,20 & 5,61 & 93,33 & $<0,001$ & 1,12 \\
\hline Motivacija & 50 & 58,12 & 7,03 & 46,98 & 10,09 & 11,14 & 6,40 & 87,50 & $<0,001$ & 1,28 \\
\hline
\end{tabular}

Opombe: v skupino nadarjenih so uvrščeni učenci, identificirani na kateremkoli področju OLNAD07. Zaradi krišitve predpostavke o

homogenosti varianc pri lestvicah intelektualnih sposobnosti in ustvarjalnosti sva za primerjavo dosežkov uporabila Welchev $t$-test. 
Tabela 7. Surovi in standardizirani povprečni dosežki na lestvicah GRS-S ter primerjava dosežkov med spoloma

\begin{tabular}{|c|c|c|c|c|c|c|c|c|c|c|}
\hline & \multicolumn{4}{|c|}{ Dečki $(n=89)$} & \multicolumn{4}{|c|}{ Dekleta $(n=86)$} & \multirow[b]{2}{*}{$t$} & \multirow[b]{2}{*}{$d$} \\
\hline & $M$ & $S D$ & $M_{\mathrm{st}}$ & $S D_{\text {st }}$ & $M$ & $S D$ & $M_{\mathrm{st}}$ & $S D_{\text {st }}$ & & \\
\hline Intelektualne sposobnosti & 59,9 & 29,7 & 49,9 & 10,2 & 62,8 & 29,0 & 50,1 & 9,7 & 0,10 & 0,02 \\
\hline Učne sposobnosti & 61,1 & 29,8 & 49,5 & 10,4 & 66,8 & 28,7 & 50,5 & 9,6 & 0,68 & 0,10 \\
\hline Ustvarjalnost & 54,8 & 26,6 & 49,2 & 9,6 & 60,4 & 26,8 & 50,9 & 10,3 & 1,19 & 0,18 \\
\hline Talent & 51,0 & 22,9 & 46,6 & 8,8 & 68,5 & 24,0 & 53,6 & 9,8 & $4,95^{*}$ & 0,75 \\
\hline Vodenje & 55,9 & 25,6 & 47,0 & 9,4 & 72,8 & 25,4 & 53,0 & 9,5 & $4,19 *$ & 0,63 \\
\hline Motivacija & 61,5 & 25,5 & 48,6 & 9,8 & 70,5 & 25,9 & 51,6 & 10,0 & $2,06^{*}$ & 0,31 \\
\hline
\end{tabular}

Opombe: analize za preverjanje razlik med spoloma so bile izvedene s standardiziranimi dosežki, $d f=173 ;{ }^{*} p<0,05$.

na lestvici umetniškega talenta $(t[173]=4,95, p<0,001$, $d=0,75), 16,9$ točk na lestvici vodstvenih sposobnosti $(t[173]=4,19, p<0,001, d=0,63)$ in 9 točk na lestvici motivacije $(t[173]=2,06, p=0,041, d=0,31)$. V tabeli 7 prikazujeva opisne statistike za dosežke na posameznih lestvicah ločene po spolu in rezultate $t$-testov za preverjanje pomembnosti razlik v dosežkih med spoloma.

\section{Konvergentna veljavnost}

Konvergentno veljavnost GRS-S sva preverjala s primerjavo z rezultati učencev na OLNAD07. Povezanost med dosežki na lestvici učnega področja OLNAD07 in intelektualnimi ter učnimi sposobnostmi je zmerno visoka ( $r=0,44$ za intelektualne in $r=0,45$ za učne sposobnosti), višje pa so povezanosti področij vodstvenih sposobnosti obeh pripomočkov $(r=0,70)$ ter področja umetniškega talenta GRS-S z literarnim, dramskim, glasbenim in likovnim področjem OLNAD07 $(r=0,53-0,63)$.

Ker so z lestvicami OLNAD07 ocenjeni le učenci, ki so bili v postopku identifikacije evidentirani, v najinem vzorcu pa so učitelji učence ocenjevali neodvisno od postopka evidentiranja, bi se pri računanju povezanosti med surovimi dosežki lahko pojavila omejitev obsega variabilnosti v skupini podatkov, zbranih z OLNAD07. Poleg opisanih povezanosti sva tako primerjala tudi skladnost izida vsakega od ocenjevalnih postopkov, torej v kolikšni meri z vsakim od pripomočkov kot nadarjene identificiramo iste učence. Ujemanje skupne ocene nadarjenosti na obeh pripomočkih je zmerno visoko $\left(r_{\text {tet }}=0,61, S E=0,09\right)$, zaradi različnih opredelitev posameznih lestvic pa v nadaljevanju predstavljava le posamezne smiselne povezanosti.

Povezanost ocen na učnem področju sva preverjala Z združitvijo ocen podlestvic intelektualnih in učnih sposobnosti GRS-S ( $T$-vrednost 63 na eni ali obeh) in lestvico učnega področja OLNAD07, ki v uporabljeni revidirani obliki združuje lestvice splošno intelektualnega, učnega področja in ustvarjalnosti. Povezanost je zmerna $\left(r_{\text {tet }}=0,50, S E=0,13\right)$, nekoliko višja pa je, če primerjamo povezanosti učne nadarjenosti OLNAD07 in učnih $\left(r_{\text {tet }}=0,59\right.$, $S E=0,13)$ ter intelektualnih sposobnosti GRS-S $\left(r_{\text {tet }}=0,52\right.$, $S E=0,14)$. Povezanost med učno nadarjenostjo na OLNAD07 in »identifikacijo" na lestvici ustvarjalnosti GRS-S je nizka $\left(r_{\text {tet }}=0,37, S E=0,16\right)$, kljub visoki povezanosti med surovimi dosežki na lestvicah.

Tudi ujemanje na področju umetniškega talenta je nizko, a pozitivno $\left(r_{\text {tet }}=0,35, S E=0,16\right)$, kar je verjetno posledica različnosti opredelitev (pri OLNAD07 so področja ločena, pri GRS-S pa je lestvica samo ena in širša). Za primerjavo s področjem umetniškega talenta na GRS-S sva uporabila skupino učencev, ki so kot nadarjeni identificirani na vsaj enem od področij literarne, dramske, glasbene in likovne nadarjenosti pri OLNAD07. Ujemanje je sicer višje na področju vodstvenih sposobnosti $\left(r_{\text {tet }}=0,58, S E=0,13\right)$, ki je v obeh pripomočkih opredeljeno podobno.

Ujemanja pričakovano niso zelo visoka, saj poleg primerjanja dihotomiziranih vrednosti, ki močno zmanjšajo variabilnost podatkov, do razhajanja prihaja tudi pri številu nadarjenih. V vzorcu je na vsaki od lestvic identificiranih $10 \%$ učencev (med 16 in 19), pri OLNAD07 pa je v vzorcu razpon večji - na posameznih lestvicah je bilo identificiranih od 14 (telesno-gibalno področje) do 30 učencev (učno področje), kar predstavlja tudi do 17 \% vseh učencev v vzorcu.

Hkrati je potrebno izpostaviti tudi časovno razliko med obema ocenjevanjema (v večini šol OLNAD07 uporabijo januarja ali februarja, GRS-S so uporabili maja in junija); ker nimamo podatkov o retestni zanesljivosti za nobenega od pripomočkov, težko ocenimo, kako časovna razlika vpliva na dosežke, a so predvsem ocene na GRS-S lahko pod vplivom učenčevih dosežkov in zaključnih ocen ob koncu leta, njegovega napredka v šolskem letu ipd. Prav tako predstavljajo učenčevi dosežki na OLNAD07 povprečje ocen različnih ocenjevalcev, ki lahko njegove sposobnosti zaznavajo drugače kot učitelj, ki ga je ocenil z lestvicami GRS-S. Slednje so glede na surovo število točk, potrebnih za uvrstitev v zgornjih $10 \%$ učencev v vzorcu, strožje od izvirnika, zato bi bilo potrebno $\mathrm{v}$ prihodnje dodatno raziskati diskriminativnost $\mathrm{v}$ zgornji tretjini porazdelitve in tako ugotoviti, ali se dosegljivost mej glede na učiteljev stil ocenjevanja med obema pripomočkoma pomembno razlikuje.

Ob upoštevanju različnih opredelitev ocenjevanih področij in lestvic bi bilo potrebno konvergentno veljavnost obeh pripomočkov še dodatno raziskati in ob tem v ocenjevanje zajeti celotne razrede. Pri podrobnem pregledu ujemanja izidov namreč ugotovimo, da le pri treh učiteljih prihaja do večjih odstopanj - na podlagi ocen z GRS-S so pri dveh učiteljih v skupino nadarjenih uvrščeni vsi učenci, nobeden od njih pa ni bil identificiran z uporabo OLNAD07. Mogoče je, da na omenjeni šoli lestvic sploh (še) niso uporabili ali podatkov niso podali, vseeno pa omenjeni rezultati vplivajo na skupne koeficiente ujemanja med obema pripomočkoma če omenjenih deset učencev iz analize izločimo, se ujemanje močno poveča $\left(r_{\text {tet }}=0,80 ; S E=0,07\right)$. Pri slabi tretjini učiteljev $(30,5 \%)$ je sicer moč opaziti popolno ujemanje med obema 
pripomočkoma - učenec bi bil kot nadarjen spoznan z obema ali z nobenim - pri ostalih do razlike prihaja pri enem ali dveh učencih.

Pomembna razlika med obema pripomočkoma je tudi način ocenjevanja, saj pri OLNAD07 učitelj oceni, v kolikšni meri trditev velja za ocenjevanega učenca, pri GRS-S pa poskuša učenca uvrstiti na razpon glede na dosežke njegovih vrstnikov v dveh korakih. Omenjena razlika lahko pomembno vpliva na dosežene rezultate, saj omogoča bolj natančno ločevanje med ocenami (tudi ocenjevalna lestvica je širša; obsega devet namesto sedem stopenj) in spodbuja k objektivnosti, ki je pri OLNAD07 vprašljiva (Juriševič idr., 2012). S tem se strinjajo tudi učitelji - oceni objektivnosti $(M=3,56)$ in razločljivosti $(M=3,96)$ pripomočka GRS-S sta pomembno višji od ocen lestvic OLNAD07 $\left(M_{\text {objektivnost }}=3,00, M_{\text {razločljivost }}=3,35\right)$.

\section{Mnenje ocenjevalcev}

Učitelji so ob koncu podali tudi svoje mnenje o GRS-S in OLNAD07, pri čemer so pri 5-stopenjski lestvici ocenjevali splošni vtis ob uporabi in posamezne vidike lestvic (npr. trajanje izpolnjevanja, razumljivost navodil). V povprečju so učitelji na podlagi splošnega vtisa ocenili lestvice GRS-S ( $n=32, M=3,94, S D=0,62$ ) kot ustreznejše od OLNAD07 ( $n=31, M=2,97, S D=0,84)$; razlika je statistično značilna $\mathrm{z}$ velikim učinkom, $t(30)=7,19, p<0,001, d=1,29$. Podobno je $\mathrm{z}$ ocenami posameznih področij, razen pri preprostosti uporabe in razumljivosti navodil. Povprečne ocene lestvic GRS-S se gibljejo med 3,03 (trajanje izpolnjevanja) ter 3,94 (razločljivost) in 3,97 (razumljivost navodil). Povprečne ocene in rezultati $t$-testov za ponovljene meritve so prikazani v tabeli 8 .

Večina učiteljev $(f=24)$ bi raje kot OLNAD07 uporabila GRS-S, trem se zdita oba pripomočka zelo podobna, dva pa bi jih raje uporabila OLNAD07 (ker se jima zdi bolj razumljiv). Preostali štirje učitelji se do uporabe OLNAD07 niso opredelili, a menijo, da so GRS-S predolge in obširne, zapletene in nerazumljive, premalo objektivne, hkrati pa pogrešajo večjo delitev po področjih. S slednjim se strinjajo tudi štirje od učiteljev, ki bi sicer raje uporabili lestvice GRS-S, a pogrešajo tehnično ter telesno-gibalno področje, saj menijo, da je trenutno GRS-S primeren predvsem za učno uspešne učence. Štirje ocenjevalci so v splošnem kritični do uporabe ocenjevalnih lestvic $\mathrm{v}$ postopku identifikacije nadarjenosti.

Kot prednosti lestvic GRS-S ocenjevalci izpostavljajo krajši čas izpolnjevanja $(f=10)$, razumljivost $(f=7)$, natančnost, sistematičnost in enoznačnost postavk $(f=8)$ lažjo in hitrejšo prepoznavo učencev v postavkah $(f=5)$, ustreznost področij $(f=5)$, spodbujanje k objektivnosti $(f=4)$, preprostost izpolnjevanja $(f=3)$ in izčrpnost $(f=1)$. Menijo, da je pripomoček dobro strukturiran in pregleden $(f=5)$; kot pozitivnega ocenjujejo dvostopenjski način ocenjevanja, s katerim lažje umestijo otroka v skupino vrstnikov $(f=5)$. Dva učitelja ob tem predlagata možnost izbire področij (izpolnjevanje postavk le na področjih, za katera menita, da so pomembna za otroka), dva pa menita, da motivacije ni smiselno ocenjevati, saj je ne zaznavata kot enega od področij nadarjenosti.

\section{Omejitve in nadaljnje raziskovanje}

V prvi vrsti predstavlja omejitev pri interpretaciji rezultatov velikost vzorca; ta je bil sicer manjši od standardizacijskega vzorca OLNAD07, a večji od vzorcev tujih študij s pripomočkom GRS-S - težava tako v prvi vrsti ni v velikosti (čeprav bi večji vzorec omogočal statistično bolj občutljive in posplošljive zaključke), ampak predvsem v načinu vzorčenja, na kar opozarjajo tudi Pfeiffer in sodelavci (2008), ki predlagajo naključno ali stratificirano vzorčenje, neodvisno od učiteljeve nominacije. Uporabljen način vzorčenja je sicer ustvaril razmeroma heterogen vzorec, a se lestvice $\mathrm{v}$ praksi ne uporabljajo pri celotnih razredih. Variabilnost rezultatov pa bi bila $\mathrm{v}$ primeru testiranja le potencialno nadarjenih verjetno manjša, kar bi lahko vplivalo tudi na nižjo zanesljivost pripomočka.

V prihodnjih raziskavah bi bilo tako z vidika zagotavljanja reprezentativne razpršenosti smiselno uporabiti način, uporabljen tudi v standardizaciji OLNAD07, kjer so učitelji ocenjevali celotne razrede in tako z večjo verjetnostjo zajeli celoten spekter potencialov in dosežkov. Tako bi zbrali vzorec, ki bi omogočal tudi izvedbo dodatnih statističnih analiz (npr. hierarhično modeliranje), ki bi nam omogočile vpogled v vplive različnih dejavnikov na ocene o učencih.

Tabela 8. Povprečne ocene različnih lastnosti obeh pripomočkov za učiteljevo oceno nadarjenosti učenca

\begin{tabular}{|c|c|c|c|c|c|c|c|c|}
\hline \multirow[b]{2}{*}{ Lastnost } & \multirow[b]{2}{*}{$n$} & \multicolumn{2}{|c|}{ OLNAD07 } & \multicolumn{2}{|c|}{ GRS-S } & \multirow[b]{2}{*}{$t$} & \multirow[b]{2}{*}{$d f$} & \multirow[b]{2}{*}{$d$} \\
\hline & & $M$ & $S D$ & $M$ & $S D$ & & & \\
\hline Preprostost uporabe & 34 & 3,44 & 0,99 & 3,24 & 1,21 & $-1,23$ & 33 & 0,21 \\
\hline Razumljivost navodil & 34 & 3,76 & 1,05 & 3,97 & 0,97 & 1,16 & 33 & 0,20 \\
\hline Razumljivost ocenjevanih področij/postavk & 33 & 3,39 & 1,03 & 3,70 & 0,85 & 1,67 & 32 & 0,29 \\
\hline Vsebinska ustreznost merjenih področij & 34 & 3,21 & 1,12 & 3,68 & 0,95 & $2,31 *$ & 33 & 0,40 \\
\hline $\begin{array}{l}\text { Izčrpnost (pripomoček zajame pomembna } \\
\text { področja nadarjenosti) }\end{array}$ & 33 & 3,21 & 1,08 & 3,55 & 0,87 & $1,94^{*}$ & 32 & 0,34 \\
\hline Objektivnost (onemogočanje subjektivnosti) & 34 & 3,00 & 0,95 & 3,56 & 0,96 & $3,79 *$ & 33 & 0,65 \\
\hline $\begin{array}{l}\text { Razločljivost (ocene se med nadarjenimi in } \\
\text { nenadarjenimi razlikujejo) }\end{array}$ & 34 & 3,35 & 1,10 & 3,94 & 0,95 & $2,90^{*}$ & 33 & 0,50 \\
\hline Trajanje izpolnjevanja $^{1}$ & 34 & 2,59 & 1,31 & 3,03 & 1,34 & $1,87 *$ & 33 & 0,32 \\
\hline
\end{tabular}

Opombe: H0 = ocena GRS-S > ocena OLNAD07. Višja ocena na lestvici od 1 do 5 pomeni višje strinjanje; $* p<0,05 ;{ }^{1} 1-$ predolgo,

5 - ustrezno 
Je pa tak način ocenjevanja mogoč zgolj ob močni institucionalni podpori javnih služb (Ministrstvo za izobraževanje, znanost in šport, Zavod Republike Slovenije za šolstvo ali drugih), saj od učiteljev in drugih strokovnih delavcev zahteva veliko časa, razmisleka in nenazadnje tudi stroškov.

Še bolj težavno je relativno majhno število sodelujočih strokovnih delavcev, pri katerih tudi nisva preverjala poznavanja področja ali zagotovila sistematičnega uvajanja $\mathrm{v}$ uporabo pripomočka, kar bi bilo $\mathrm{v}$ prihodnje smiselno zagotoviti. Z zbiranjem ocen različnih ocenjevalcev bi lahko preverjali tudi objektivnost rezultatov, s sočasno uporabo pripomočkov za oceno inteligentnosti in ustvarjalnosti pa zunanjo veljavnost.

Iz vsebinskega vidika bi v prihodnje lahko razmišljali o načinih vključitve telesno-gibalnega in tehničnega področja (s spremembo ali zamenjavo obstoječih postavk ali oblikovanjem dodatnih lestvic) in razmislili, kakšna je vloga lestvice motivacije $\mathrm{v}$ našem prostoru. Ker nekateri učitelji lestvice še vedno zaznavajo kot predolge in preobsežne, nekaterapodročjain postavkepaševednozahtevajopoznavanje učenca v okoljih, ki nekaterim ocenjevalcem niso poznana, bi bilo smiselno preučiti tudi možnosti izbire ocenjevanih področij (učitelj ne izpolni vseh, ampak le izbrane lestvice). Bi pa bilo pri tem, poleg vpliva na merske značilnosti, potrebno premisliti o strokovni smiselnosti takšnega početja: če učitelj izbira lestvice, je mogoče, da bo izbral le tiste lestvice in učence, ki bodo visoko ocenjeni (in verjetno identificirani), kar je v nasprotju z osnovnim ciljem uporabe instrumentarija $\mathrm{v}$ postopku identifikacije.

\section{Zaključki}

Kljub zapisanim omejitvam so učitelji, ki so sodelovali V študiji, nov pripomoček dobro sprejeli; ocenjujejo ga kot objektivnejšega in primernejšega od OLNAD07 (nekateri izpostavljajo tudi natančnost, sistematičnost in enoznačnost postavk, kar predstavlja nadgradnjo obstoječega pripomočka). Ob utemeljenosti lestvic GRS-S na preverjenem teoretičnem ozadju, ki je skladno s slovenskimi opredelitvami, spodbudnimi rezultati iz tujine in nenazadnje rezultati pričujoče študije, ki kažejo na ustrezno diskriminativnost, zanesljivost in veljavnost prevedenih lestvic (ustrezna notranja in kriterijska veljavnost, šestfaktorska struktura, konvergentna veljavnost, primerljivost $\mathrm{z}$ izvirnikom), se zdi smiseln nadaljnji razvoj pripomočka. Ta bi moral vključevati preverjanje merskih značilnosti pri večjem, reprezentativnem in starostno heterogenem vzorcu (npr. zgoraj opisano stratificirano ali slučajnostno vzorčenje) ter preverjanje retestne zanesljivosti, $\mathrm{ki}$ bi omogočala kontinuirano spremljanje nadarjenih. Ker koncept dela $\mathrm{z}$ nadarjenimi predvideva tudi zbiranje več ocen o posameznem učencu, bi bilo potrebno preveriti, kakšna je skladnost ocenjevalcev ter kakšen je možni vpliv značilnosti učiteljev in šolskega okolja na ocene posameznih učencev. Vpeljava ustrezno preverjenih lestvic GRS-S v uporabo se zdi smiselna tudi zato, ker bi lahko $\mathrm{z}$ njimi bolj korektno identificirali nadarjene ter prispevali $\mathrm{k}$ zmanjševanju deleža identificiranih učencev. V nadaljevanju bi tako učitelji imeli več časa in sredstev za prepoznavanje in delo z nadarjenimi, kar bi lahko vodilo tudi do oblikovanja bolj pozitivnih stališč in višje motiviranosti za delo z njimi.

\section{Literatura}

Beretta, A., Pfeiffer, S. in Zanetti, M. A. (2014, september). Validation of Italian version of Gifted Rating ScalesSchool Form: Preliminary data. Predstavljeno na 14. International ECHA Conference, Ljubljana. http:// echa2014.mib.si/programme/contributions/65/

Bezić, T. in Deutsch, T. (2011). Analiza uresničevanja Koncepta: Odkrivanje in delo z nadarjenimi učenci $v$ devetletni OŠ, ob koncu šol. leta 2009/2010: Poročilo $o$ raziskavi [Analysis of Concept implementation: Recognizing and working with gfited students in primary schools at the end of 2009/2010 school year: Research report]. Zavod Republike Slovenije za šolstvo.

Bezić, T., Žagar, D., Artač, J. in Nagy, M. (2009). Operacionalizacija Koncepta odkrivanja in delo $z$ nadarjenimi učenci $v$ devetletni osnovni šoli [Operationalization of the Concept of discovering and working with gifted students in a nine-year elementary school]. Zavod Republike Slovenije za šolstvo.

Boben, D. (2006). Identifikacija po Konceptu in pripomočki zanjo [Concept-based identification and instruments for it]. V T. Bezić, A. Blažič, D. Boben, M. Brinar Huš, M. Marovt, M. Nagy in D. Žagar (ur.), Odkrivanje nadarjenih učencev in vzgojno-izobraževalno delo $z$ njimi [Discovering talented students and educational work with them] (str. 54-69). Zavod Republike Slovenije za šolstvo.

Brown, S. W., Renzulli, J. S., Gubbins, E. J., Siegle, D., Zhang, W. in Chen, C. H. (2005). Assumptions underlying the identification of gifted and talented students. Gifted Child Quarterly, 49(1), 68-79.

Cseh, A. (2011). Programmes of talent identification and talent management in Slovenia. V J. G. Győri (ur.), International horizons of talent support: Vol. 1. Best practices within and out of the European Union (str. 166-182). Genius Konyvek 18.

Davidson, J. E. (2009). Contemporary models of giftedness. V L. V. Shavinina (ur.), International handbook on giftedness (str. 81-97). Springer Netherlands.

de Cássia Nakano, T. in Siqueira, L. G. G. (2012). Validade de conteúdo da Gifted Rating Scale (versão escolar) para a população brasileira [Content validity of the Gifted Rating Scale (school version) for the Brazilian population]. Avaliaçao Psicologica, 11(1), 123-140.

Ekspertna skupina za delo $\mathrm{z}$ nadarjenimi $\mathrm{v}$ osnovni in srednji šoli. (2008). Ocenjevalne lestvice nadarjenosti učenca: Izpopolnjena oblika 2007 (OLNAD07) [Rating scales of giftedness in students: Revised version 2007 (OLNAD07)]. Zavod Republike Slovenije za šolstvo.

Erwin, J. O. in Worrell, F. C. (2012). Assessment practices and the underrepresentation of minority students in gifted and talented education. Journal of Psychoeducational Assessment, 30(1), 74-87.

Freeman, J., Raffan, J. in Warwick, I. (2010). Worldwide provision to develop gifts and talents: An international survey research report. http://www.joanfreeman.com/ pdf/towereport.pdf 
Győri, J. G. (2013). Best practices in international talent nurturing and support: Reflections, lessons and questions. V J. G. Györi (ur.), National horizons of talent support: Vol. I. Best practices within and out of the European Union. Genius Konyvek 18.

Heller, K. A. (2004). Identification of gifted and talented students. Psychology Science, 46(3), 302-323.

Heller, K. A., Mönks, F. J., Sternberg, R. J. in Subotnik, R. F. (ur.). (2000). International handbook of giftedness and talent (2nd ed.). Elsevier Science.

Hassan Hemdan Mohamed, A., Mahdi Kazem, A., Pfeiffer, S., Alzubaidi, A.-Q., Abu Elwan, R., Ambosaidi, A., AlWashahiin, M. in Al-Kharosi, T. (2017). Identification of gifted students in Oman: Gender and grade differences on the Gifted Rating Scales - School Form. Journal for the Education of the Gifted, 40(3), 289-301.

Jarosewich, T., Pfeiffer, S. I. in Morris, J. (2002). Identifying gifted students using teacher rating scales: A review of existing instruments. Journal of Psychoeducational Assessment, 20(4), 322-336.

Juriševič, M. (2011). Vzgoja in izobraževanje nadarjenih [Education of the gifted]. V J. Krek in M. Metljak (ur.), Bela knjiga o vzgoji in izobraževanju v Republiki Sloveniji [White Paper on education in the Republic of Slovenia] (str. 329-345). Zavod Republike Slovenije za šolstvo.

Juriševič, M. (2012). Nadarjeni učenci v slovenski šoli [The gifted in Slovenian schools]. Pedagoška fakulteta Univerze v Ljubljani.

Juriševič, M., Stritih, B., Fabjančič, N. in Gradišek, P. (2012). Pogled na delo $\mathrm{z}$ nadarjenimi $\mathrm{v}$ slovenskem šolskem prostoru $\mathrm{s}$ perspektive psihologov praktikov [Working with gifted in Slovenia from the perspective of psychologists in practice]. V M. Juriševič in B. Stritih (ur.), Posvetovanje Vloga psihologa v vzgoji in izobraževanju nadarjenih (str. 119-132). Pedagoška fakulteta Univerze v Ljubljani.

Karadağ, F., Karabey, B. in Pfeiffer, S. (2016). Identifying gifted preschoolers in Turkey: The reliability and validity of the Turkish-translated version of the GRS-Preschool/ Kindergarten Form. Journal of Education and Training Studies, 4(10), 8-16.

Kaufman, J. C. in Sternberg, R. J. (2019) (ur.). The Cambridge handbook of creativity. Cambridge University Press.

Lee, D. in Pfeiffer, S. I. (2006). The reliability and validity of a Korean-translated version of the gifted rating scales. Journal of Psychoeducational Assessment, 24(3), 210-224.

Li, H., Lee, D., Pfeiffer, S. I., Kamata, A., Kumtepe, A. T. in Rosado, J. (2009). Measurement invariance of the Gifted Rating Scales-School Form across five cultural groups. School Psychology Quarterly, 24(3), 186-198.

Li, H., Lee, D., Pfeiffer, S. I. in Petscher, Y. (2008a). Parent ratings using the Chinese version of the Parent Gifted Rating Scales-School Form: Reliability and validity for Chinese students. Educational and Psychological Measurement, 68(4), 659-675.

Li, H., Pfeiffer, S. I., Petscher, Y., Kumtepe, A. T. in Guofang, M. (2008b). Validation of the Gifted Rating Scales-School Form in China. Gifted Child Quarterly, 52(2), 160-169.
McClain, M.-C. in Pfeiffer, S. (2012). Identification of gifted students in the United States Today: A look at state definitions, policies, and practices. Journal of Applied School Psychology, 28(1), 59-88.

Petscher, Y. in Li, H. (2008). Measurement invariance of the Chinese Gifted Rating Scales. Journal of Psychoeducational Assessment, 26(3), 274-286.

Pfeiffer, S. I. in Jarosewich, T. (2003). GRS - Gifted Rating Scales: Manual. Pearson.

Pfeiffer, S. I. in Jarosewich, T. (2007). The Gifted Rating Scales-School Form. Gifted Child Quarterly, 51(1), $39-50$.

Pfeiffer, S. I. in Petscher, Y. (2008). Identifying young gifted children using the gifted rating scales-preschool/ kindergarten form. Gifted Child Quarterly, 52(1), 19-29.

Pfeiffer, S. I., Petscher, Y. in Jarosewich, T. (2007). The gifted rating scales-preschool/kindergarten form: An analysis of the standardization sample based on age, gender, and race. Roeper Review, 29(3), 206-211.

Pfeiffer, S. I., Petscher, Y. in Kumtepe, A. (2008). The Gifted Rating Scales-School Form: A validation study based on age, gender, and race. Roeper Review, 30(2), 140-146.

Podsakoff, P. M., MacKenzie, S. B., Lee, J. Y. in Podsakoff, N. P. (2003). Common method biases in behavioral research: A critical review of the literature and recommended remedies. Journal of Applied Psychology, 88(5), 879-903.

Razpotnik, B. (2018). Prebivalstvo po naseljih, podrobni podatki, Slovenija, 1. januar 2018 [Population by settlements, detailed data, Slovenia, January 1st 2018]. Statistični urad Republike Slovenije. (Pridobljeno 16. 7. 2018 s http://www.stat.si/StatWeb/News/Index/7442)

Rosado, J. I., Pfeiffer, S. I. in Petscher, Y. (2008). The reliability and validity of a Spanish translated version of the Gifted Rating Scales. Gifted and Talented International, 23(1), 105-114.

Rosado, J. I., Pfeiffer, S. in Petscher, Y. (2015). Identifying gifted students in Puerto Rico: Validation of a Spanish translation of the Gifted Rating Scales. Gifted Education International, 31(2), 162-175.

Rosseel, Y. (2012). lavaan: An R Package for Structural Equation Modeling. Journal of Statistical Software, 48(2), 1-36.

Shore, B. M., Cornell, D. G., Robinson, A. in Ward, V. S. (1991). Recommended practices in gifted education: A critical analysis. Teachers College Press.

Siu, A. F. Y. (2010). The reliability and validity of a Chinesetranslated version of the Gifted Rating Scale-Preschool/ Kindergarten Form. Journal of Psychoeducational Assessment, 28(3), 249-258.

Sternberg, R. J. in Davidson, J. E. (ur.). (2005). Conceptions of giftedness (2nd ed.). Cambridge University Press.

Stoeger, H. (2009). The history of giftedness research. V L. V. Shavinina (ur.), International handbook on giftedness (str. 17-38). Springer Netherlands.

Subotnik, R. F., Olszewski-Kubilius, P. in Worrell, F. C. (2011). Rethinking giftedness and gifted education. Psychological Science in the Public Interest, 12(1), 3-54. 
Yarnell, J. B. in Pfeiffer, S. I. (2015). Internet administration of the paper-and-pencil Gifted Rating Scale. Journal of Psychoeducational Assessment, 33(6), 534-543.

Žagar, D. (2012). Metodologija odkrivanja nadarjenih učencev v Sloveniji: Zakaj tako in kaj spremeniti [Methodology of recognizing gifted students in Slovenia: Why this way and what to change]. V M. Juriševič in B. Stritih (ur.), Posvetovanje Vloga psihologa v vzgoji in izobraževanju nadarjenih (str. 19-26). Pedagoška fakulteta Univerze v Ljubljani.

Žagar, D., Artač, J., Bezić, T., Nagy, M. in Purgaj, S. (1999). Koncept Odkrivanje in delo $z$ nadarjenimi učenci $v$ devetletni osnovni šoli [Concept of recognizing and working with gifted students in nine-year primary school]. Zavod Republike Slovenije za šolstvo. 